\title{
PROFIL KEMAMPUAN BERPIKIR ANALISIS SISWA PADA MATERI PENCEMARAN LINGKUNGAN
}

\author{
Eka Kartikawati, Astri Fajar Cahyani dan Gufron Amirullah \\ Universitas Muhammadiyah Prof. DR. HAMKA \\ Email: eka.kartikawati@uhamka.ac.id, asrifajar03@gmail.com dan \\ Gufron.amirullah@uhamka.ac.id
}

\section{Abstract}

analytical thinking skills is one of the higher order thinking abilities that must be have by students. Through analytical thinking students can see an overall problem to find the core problems that occur in everyday life and find ways to solve them. This research investigates students' analytical thinking skills on environmental pollution material and the factors that influence it. A total of 101 students of Class XI MIPA were used as research samples, Samples were taken in a way of the Random Sampling Cluster. Data were collected using analytical thinking skills test questions, questionnaires and interviews to teachers. Analysis of data using descriptive statistics with the percentage formula (NP). Based on the results of data analysis, it can be described that students' analytical thinking skills on three indicators, namely organizing by $73.49 \%$ (good), differentiating by $66.90 \%$ (good) and contributing by $76.57 \%$ (good). Supporting factors from internal and external factors in the form of reference sources (82.89\%), learning method (84.86\%) and learning evaluation (87.06\%). Inhibiting factors from internal and external factors such as intelligence (47.76\%), student interest (60.20\%) and environment (52.82\%). The analytical thinking skills of students of class XI MIPA in Senior high school 4 of Bekasi are included in the good category. There are supporting and inhibiting factors that influence it.

Keywords: Analytical Thinking, Environmental pollution

\section{Abstrak}

Kemampuan berpikir analisis merupakan salah satu kemampuan berpikir tingkat tinggi yang harus dimiliki oleh siswa. Melalui berpikir analisis siswa dapat melihat suatu permasalahan secara menyeluruh untuk menemukan inti permasalahan yang terjadi dikehidupan sehari-hari serta mencari cara penyelesaiannya. Studi ini meyelidiki tentang kemampuan berpikir analisis siswa pada materi pencemaran lingkungan dan faktor-faktor yang mempengaruhinya. Sebanyak 101 siswa kelas XI MIPA yang digunakan sebagai sampel penelitian, sampel diambil dengan cara Cluster Random Sampling. Data dikumpulkan menggunakan soal tes kemampuan berpikir analisis, kuesioner dan wawancara guru. Analisis data menggunakan statistik deskriptif dengan rumus persentase (NP). Berdasarkan hasil analisis data dapat deskripsikan bahwa kemampuan berpikir analisis siswa pada tiga indikator, yaitu mengorganisasi sebesar 73,49\% (baik), membedakan sebesar 66,90\% (baik) dan mengatribusi sebesar 76,57\% (baik). Faktor pendukung dari faktor internal dan 
eksternal berupa sumber referensi $(82,89 \%)$, metode pembelajaran $(84,86 \%)$ dan evaluasi pembelajaran $(87,06 \%)$. Faktor penghambat dari faktor internal dan eksternal berupa Intelegensi $(47,76 \%)$, minat siswa $(60,20 \%)$ dan lingkungan $(52,82 \%)$. Kemampuan berpikir analisis siswa kelas XI MIPA di SMA Negeri 4 Kota Bekasi termasuk kedalam kategori baik. Terdapat faktor pendukung dan penghambat yang mempengaruhinya.

Kata kunci: Berpikir Analisis, Pencemaran Lingkungan

\section{Pendahuluan}

Pendidikan merupakan suatu usaha untuk mengembangkan potensi atau kemampuan yang dimiliki oleh siswa secara aktif dalam proses pembelajaran (Triwiyanto, 2014). Proses pembelajaran idealnya semua peserta didik terlibat aktif sehingga dalam proses pembelajaran, bukan hanya peserta didik tertentu saja yang aktif (Firdaus, 2017). Pemerintah terus berusaha dalam meningkatkan kualitas pendidikan di Indonesia dengan menetapkan Undang-Undang Nomor 20 tahun 2003 berisi tentang Pendidikan Nasional (UU Sisdiknas) yang bertujuan agar seluruh masyarakat Indonesia mendapatkan kesempatan pendidikan yang bermutu secara merata, sehingga mereka dapat menghadapi tantangan sesuai dengan tuntutan perubahan zaman. Kurikulum 2013 merupakan kurikulum yang saat ini berlaku dalam Sistem Pendidikan Indonesia. Kurikulum 2013 diharapkan dapat menghasilkan siswa yang aktif, produktif, serta mampu berpikir kreatif, kritis, dan analisis dalam proses pembelajaran.

Kemampuan berpikir analisis merupakan kemampuan berpikir yang menentukan sesuatu berdasarkan pada situasi, praktik, masalah, pernyataan, teori, ide, dan pendapat dari masing-masing (Thaneerananon \& Triampo, 2016). Seorang siswa dikatakan memiliki kemampuan berpikir analisis yang baik ketika ia mampu mengidentifikasi suatu masalah, membedakan materi yang relevan dan tidak relevan, menghubungkan ide-ide, membuat hipotesis atau kesimpulan, dan mampu menangkap pendapatpendapat yang tersirat (Anderson \& Krathwohl, 2010). Oleh karena itu, kemampuan berpikir analisis sangat diperlukan oleh siswa agar mereka tidak mudah menerima informasi yang didapatkan dari media tanpa menganalisis atau mencari tahu terlebih dahulu kebenaran dari informasi tersebut.

Kemampuan berpikir analisis sebagai hasil belajar dapat dipengaruhi oleh faktor internal dan eksternal. Faktor internal adalah faktor yang berasal dari dalam diri individu yang sedang belajar, sedangkan faktor eksternal adalah faktor yang berasal dari luar diri individu yang sedang belajar (Slameto, 2013). Faktor internal terdiri dari minat siswa, sumber referensi, kebiasaan belajar, intelegensi, kondisi fisik dan psikis. Sedangkan faktor eksternal terdiri dari metode pembelajaran, media pembelajaran, tampilan media pembelajaran, kegiatan pembelajaran, evaluasi pembelajaran, dan lingkungan. Di dalam proses pembelajaran, faktor-faktor tersebut harus diperhatikan agar siswa memiliki hasil belajar berupa kemampuan berpikir analisis yang baik. Meskipun kemampuan berpikir analisis termasuk ke dalam kemampuan yang penting dimiliki oleh siswa, namun berdasarkan hasil survey Program of International Student 
Assessment (PISA) tahun 2015 yang diselenggarakan oleh Organisation for Economic Cooperation and Development (OECD) menunjukkan bahwa kemampuan siswa di Indonesia dalam bidang sains berada pada peringkat 62 dengan skor 403 dari 69 negara yang berpartisipasi (PISA, 2016). Sedangkan berdasarkan hasil Tren Studi Matematika dan Sains Interrnasional (TIMSS) pada tahun 2015 pencapaian peringkat siswa Indonesia selalu termasuk ke dalam negara berperingkat rendah. Rendahnya hasil TIMSS disebabkan kerena siswa Indonesia belum terbiasa berurusan dengan masalah yang memerlukan aspek keterampilan berpikir tingkat tinggi, yaitu masalah yang memerlukan penalaran, penerapan, analisis, evaluasi, dan penciptaan (Prawita \& Prayitno, 2019). Rendahnya kemampuan berpikir analisis siswa juga diperkuat oleh (Djiwandono, 2013) menyatakan bahwa kemampuan berpikir analisis pada sebagian siswa di Indonesia masih rendah (Sulastri, Safahi, \& Susilo, 2018). Selain itu, menurut hasil penelitian Sudibyo (2016) menunjukkan bahwa kemampuan siswa dalam menganalisis mekanisme aktivitas olahraga masih relatif sangat rendah dengan tingkat penguasaan 3,24\%. Siswa masih kesulitan dalam membaca grafik, memperkirakan, dan membandingkan kinerja atlet (Sudibyo, Jatmiko, \& Widodo, 2016).

Pada pelajaran Ilmu Pengetahuan Alam (IPA) khususnya biologi, terdapat materi-materi yang erat kaitannya, dengan permasalahan di kehidupan sehari-hari. Salah satu materi tersebut adalah materi pencemaran lingkungan. Pada materi ini siswa akan dihadapkan dengan berbagai permasalahan yang ada di lingkungan sekitarnya, hal ini akan merangsang siswa untuk mencari tahu dan berusaha menyelesaikan masalah tersebut.

Studi ini bertujuan untuk mengetahui seberapa besar kemampuan berpikir analisis siswa pada materi pencemaran lingkungan dan faktor-faktor apa saja yang mempengaruhinya. Studi ini belum banyak dilakukan karena untuk mengukur kemampuan berpikir analisis siswa mereka mengunakan berbagai model pembelajaran. Hasil studi ini diharapkan dapat memberi informasi lebih mendalam mengenai kemampuan awal siswa dalam berpikir analisis pada materi pencemaran lingkungan.

\section{Metode Penelitian}

Metode penelitian yang digunakan yaitu metode campuran (Mixed Methods) dengan desain sequential explanatory yang menghubungkan antara metode kuantitatif dan metode kualitatif secara berurutan, dimana pada tahap pertama menggunakan metode kuantitatif dan pada tahap kedua menggunakan metode kualitatif (Sugiyono, 2013; (Rahma, Sulhadi, \& Sumarti, 2016). Penelitian dilaksanakan di kelas XI MIPA SMA Negeri 4 Kota Bekasi semester ganjil tahun ajaran 2019-2020 pada bulan September 2019. Penelitian ini terdiri atas tiga kelas yaitu XI MIPA 1, XI MIPA 3 dan XI MIPA 4. Sampel penelitian berjumlah 101 siswa yang terdiri atas 37 siswa laki-laki dan 64 siswa perempuan ditentukan dengan teknik cluster random sampling untuk menentukan kelompok mana yang akan digunakan sebagai sumber data.

Prosedur penelitian yang dilakukan terbagi menjadi 3 tahapan yaitu: tahap awal (persiapan) dilakukan dengan mendatangi tempat penelitian yaitu SMA Negeri 4 Kota 
Bekasi untuk meminta izin kepada pihak sekolah, konsultasi instrumen dengan dosen pembimbing, melakukan validitas secara konstruk dan empiris instrumen soal yang akan digunakan. Selanjutnya tahap inti (pelaksanaan) dilakukan dengan cara menyebar instrumen soal dan angket kepada siswa, serta melakukan wawancara kepada guru biologi. Tahap akhir dalam penelitian ini adalah data yang diperoleh dianalisis untuk menarik kesimpulan pada penelitian.

Instrumen yang digunakan dalam penelitian berupa tes tertulis berbentuk pilihan ganda, angket dan wawancara. Tes kemampuan berpikir analisis siswa yang terdiri dari 3 indikator yaitu: mengorganisasi, membedakan dan mengatribusi. Instrumen penelitian sebanyak 30 butir soal pilihan ganda. setelah itu, instrumen soal dilakukan uji coba soal seperti: uji validitas, uji reliabilitas, tingkat kesukaran dan daya pembeda soal. Uji validitas soal menggunakan uji korelasi point biserial, hasil uji coba validitas soal menunjukkan 25 soal valid dan 5 soal tidak valid. Rumus korelasi point biserial menurut (Suharsimi, 2006) dapat dituliskan sebagai berikut:

$$
\mathrm{r}_{\mathrm{pbis}}=\frac{\mathrm{M}_{\mathrm{p}}-\mathrm{M}_{\mathrm{t}}}{\mathrm{Sd}_{\mathrm{t}}} \sqrt{\frac{\mathrm{p}}{\mathrm{q}}}
$$

Keterangan:

$\mathrm{r}_{\mathrm{pbis}}=$ Koefisien korelasi point biserial

$\mathrm{M}_{\mathrm{p}}=$ Skor rata-rata hitung untuk butir soal yang dijawab benar

$\mathrm{M}_{\mathrm{t}}=$ Skor rata-rata dari skor total

$\mathrm{Sd}_{\mathrm{t}}=$ Standar deviasi skor total

$\mathrm{p}=$ Proporsi siswa yang menjawab benar pada butir soal yang diuji validitasnya

$\mathrm{q}=$ Proporsi siswa yang menjawab salah pada butir soal yang diuji validitasnya

Adapun rumus Spearman-Brown yang digunakan untuk menguji reliabilitas menurut (Arikunto, 2009), sebagai berikut:

$$
r_{11}=\frac{2 r_{1 / 2}^{1 / 2}}{\left(1+r_{1 / 2} 1_{2}\right)}
$$

Keterangan:

$r_{1 / 2}^{1 / 2}=$ Korelasi antara skor-skor belahan atas

$r_{11}=$ Koefisien reliabilitas yang sudah disesuaikan

Menurut (Ngalim, 2011) tingkat kesukaran soal pilihan ganda dapat diperoleh dengan menggunakan rumus, sebagai berikut:

$$
\mathrm{TK}=\frac{\mathrm{U}+\mathrm{L}}{\mathrm{T}}
$$

Keterangan:

TK = Indeks kesukaran yang dicari

$\mathrm{U}=$ Jumlah siswa yang termasuk upper group yang menjawab benar pada tiap soal 
$\mathrm{L}=\quad$ Jumlah siswa yang termasuk lower group yang menjawab benar pada tiap soal

$\mathrm{T}=$ Jumlah siswa dari kelompok upper dan lower group

Selanjutnya daya pembeda soal pilihan ganda dapat diperoleh dengan menggunakan rumus, sebagai berikut:

$$
\mathrm{DP}=\frac{\mathrm{U}-\mathrm{L}}{1 / 2 \mathrm{~T}}
$$

Keterangan:

$\mathrm{DP}=$ Indeks daya pembeda

$\mathrm{U}=$ Jumlah siswa yang termasuk upper group yang menjawab benar pada tiap soal

$\mathrm{L}=\quad$ Jumlah siswa yang termasuk lower group yang menjawab benar pada tiap soal

$\mathrm{T}=$ Jumlah siswa dari kelompok upper dan lower group

Instrumen soal kemampuan berpikir analisis yang digunakan untuk olah data terdiri dari 25 butir soal pilihan ganda dan 18 butir soal angket untuk mengetahui faktor-faktor yang mempengaruhi kemampuan berpikir analisis siswa. Hasil data yang diperoleh dianalisis menggunakan statistik deskriptif dengan rumus persentase (NP), sebagai berikut:

$$
\mathrm{NP}=\frac{\mathrm{R}}{\mathrm{SM}} \times 100 \%
$$

Keterangan:

$\mathrm{NP}=$ Nilai persen yang dicari atau diharapkan

$\mathrm{R}=$ Skor mentah yang diperoleh siswa

$\mathrm{SM}=$ Skor maksimum ideal dari tes yang bersangkutan

$100=$ Bilangan tetap

\section{Hasil dan Pembahasan}

\section{A. Hasil}

Data yang diperoleh dari penelitian ini merupakan data kemampuan berpikir analisis siswa pada materi pencemaran lingkungan dan data mengenai faktor-faktor yang mempengaruhi kemampuan analisis siswa.

\section{Hasil analisis tes kemampuan berpikir analisis siswa}

Data penelitian dari instrumen tes tertulis digunakan untuk mengetahui kemampuan berpikir analisis siswa yang diperoleh dengan mengujikan 25 soal pilihan ganda materi pencemaran lingkungan. hasil persentase perindikator dari tes tertulis dapat dilihat pada gambar 1 . 


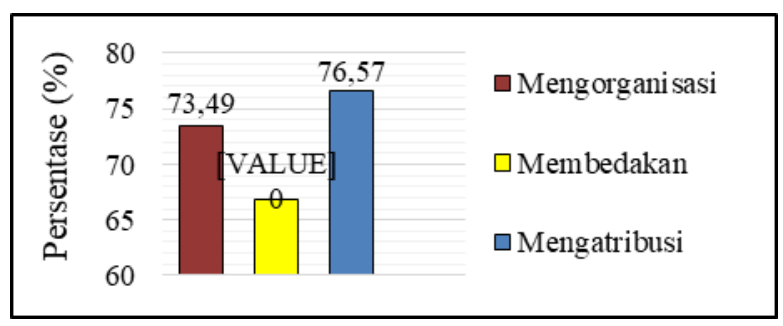

\section{Gambar 1 Diagram Batang Persentase Indikator Kemampuan Berpikir Analisis}

Diagram di atas menunjukkan persentase tertinggi kemampuan berpikir analisis siswa terdapat pada indikator mengatribusi $(76,57 \%)$, kemudian indikator mengorganisasi $(73,49 \%)$, dan persentase terendah terdapat pada indikator membedakan $(66,90 \%)$.

2. Hasil Analisis Angket Faktor yang Mempengaruhi Kemampuan Berpikir Analisis Siswa

Secara umum terdapat beberapa faktor yang mempengaruhi kemampuan berpikir analisis siswa. Faktor tersebut terdiri dari faktor internal dan faktor eksternal. Faktor internal terdiri dari minat siswa, sumber referensi, kebiasaan belajar, intelegensi, kondisi fisik dan psikis. Sedangkan faktor eksternal terdiri dari metode pembelajaran, media pembelajaran, tampilan media pembelajaran, kegiatan pembelajaran, evaluasi pembelajaran, dan lingkungan. Rata-rata persentase faktor internal yang mempengaruhi kemampuan berpikir analisis siswa terdapat pada gambar 2 .



\section{Gambar 2 Diagram Batang Rata-Rata Persentase Faktor Internal yang Mempengaruhi Kemampuan Analisis Siswa}

Gambar 2 menunjukkan rata-rata persentase faktor internal yang berbeda-beda. Sumber referensi yang digunakan oleh siswa memiliki rata-rata persentase tertinggi $(82,89 \%)$, dan rata-rata persentase terendah terdapat pada Intelegensi $(47,76 \%)$.

Rata-rata persentase faktor eksternal yang mempengaruhi kemampuan berpikir analisis terdapat pada gambar 3. 


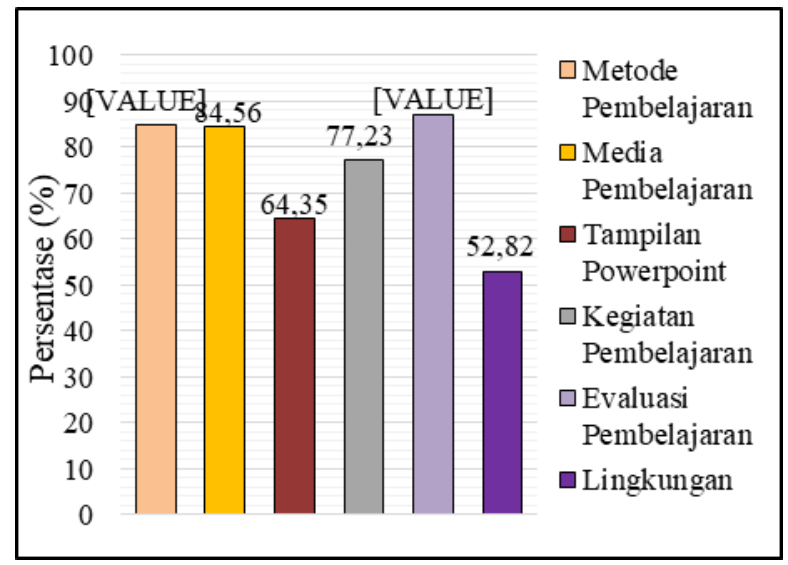

\section{Gambar 3 Diagram Batang Rata-Rata Persentase Faktor Eksternal yang Mempengaruhi Kemampuan Analisis Siswa}

Gambar 3 menunjukkan rata-rata persentase faktor eksternal yang berbeda-beda. Evaluasi pembelajaran yang digunakan oleh siswa memiliki rata-rata persentase tertinggi $(87,06 \%)$, dan rata-rata persentase terendah terdapat pada lingkungan $(52,82 \%)$.

Selain itu, berdasarkan hasil perhitungan persentase butir angket yang berasal dari faktor eksternal yaitu metode pembelajaran. Terdapat beberapa metode yang digunakan oleh guru untuk meningkatkan kemampuan analisis siswa dalam proses pembelajaran seperti pembelajaran berbasis masalah, pengamatan (inkuiri) dan tanya jawab yang terdapat pada gambar 4 .

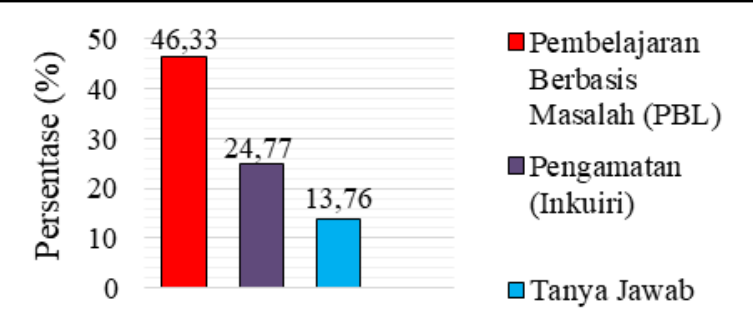

\section{Gambar 4 Diagram Batang Rata-Rata Persentase Faktor Eksternal yaitu Metode Pembelajaran}

Gambar 4 menunjukkan persentase siswa yang merasa bahwa guru menggunakan metode pembelajaran berbasis masalah sebesar (46,33\%). Sedangkan siswa yang merasa dalam proses pembelajaran guru menggunakan metode pengamatan (inkuiri) sebesar $(24,77 \%)$ dan metode tanya jawab sebesar dan $(13,76 \%)$.

Berdasarkan hasil perhitungan persentase butir angket yang berasal dari lingkungan terdapat beberapa faktor yang mempengaruhi kemampuan berpikir analisis siswa yaitu peran keluarga, peran teman sebaya, dan tempat bimbingan belajar (bimbel). Hal ini terdapat pada gambar 5 . 


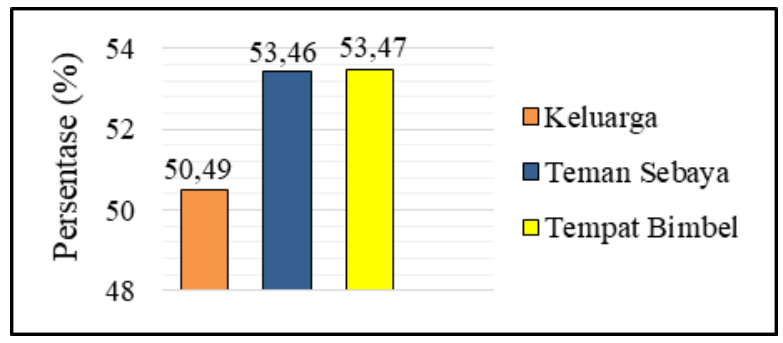

\section{Gambar 5 Diagram Batang Rata-Rata Persentase Faktor Eksternal yaitu Lingkungan}

Gambar 5 menunjukkan persentase siswa yang merasa bahwa saat belajar di tempat bimbel sering mendapatkan tes tertulis atau lisan yang dapat melatih kemampuan analisis sebesar $(53,47 \%)$. Sedangkan peran teman sebaya dan keluarga dalam melatih kemampuan analisis siswa sebesar $(53,46 \%)$ dan $(50,49 \%)$.

\section{Hasil Wawancara Guru}

Berdasarkan hasil wawancara dengan guru biologi kelas $\mathrm{X}$ di SMA Negeri 4 Kota Bekasi menunjukkan bahwa untuk meningkatkan kemampuan analisis siswa guru menggunakan metode pembelajaran berbasis masalah (Problem Based Learning) pada materi pencemaran lingkungan. Media pembelajaran yang digunakan oleh guru pada materi pencemaran lingkungan yaitu media powerpoint, video, gambar. Sedangkan pada sub pokok bahasan proses daur ulang sampah guru menggunakan sampah-sampah organik dan sampah-sampah anorganik yang ada di sekitar sekolah. Dalam mengembangkan kemampuan analisis siswa di dalam kelas guru tidak memiliki kendala. Kendala yang dirasakan oleh guru hanya terdapat pada fasilitas laboratorium, seperti alat dan bahan yang masih kurang memadai untuk menunjang siswa dalam melaksanakan praktikum pada materi pencemaran lingkungan, sehingga guru hanya memanfaatkan apa saja yang ada di lingkungan sekolah. Selain itu, dalam proses pembelajaran guru sering memberikan tugas kepada siswa untuk menganalisis suatu kejadian berdasarkan gambar atau video yang diberikan, seperti kebakaran hutan yang terjadi di Indonesia dan dampak apa yang akan ditimbulkan pada lingkungan sekitar. Setiap akhir pembelajaran guru juga memberikan tes tertulis atau tes lisan yang dapat meningkatkan kemampuan analisis siswa.

Upaya lain yang dilakukan oleh pihak sekolah dan guru untuk meningkatkan kemampuan berpikir analisis siswa adalah setiap hari Jumat seluruh siswa diminta berkumpul di lapangan untuk mengikuti kegiatan memilah atau memisahkan berbagai jenis sampah organik dan anorganik yang ada di lingkungan sekolah. Selanjutnya pada hari rabu seluruh siswa mengolah berbagai jenis sampah organik maupun sampah anorganik yang telah mereka pisahkan sebelumnya untuk dijadikan produk atau barang yang dapat 
dimanfaatkan kembali, kegiatan ini dilakukan selama 15 menit sebelum proses pembelajaran dimulai.

\section{A. Pembahasan}

Setelah melakukan analisis data didapatkan hasil kemampuan berpikir analisis siswa kelas XI MIPA di SMA Negeri 4 Kota Bekasi termasuk ke dalam kategori baik dengan rata-rata persentase sebesar $73 \%$. Selain itu, melalui hasil perhitungan angket diketahui terdapat faktor pendukung dan faktor penghambat yang mempengaruhi kemampuan berpikir analisis siswa. Indikator mengatribusi, mengorganisasi, dan membedakan merupakan indikator yang tergolong ke dalam kategori baik. Hal tersebut dapat disebabkan oleh adanya faktor pendukung yang berasal dari faktor internal dan faktor eksternal. Faktor pendukung yang berasal dari faktor internal adalah sumber referensi, dan faktor pendukung yang berasal dari faktor eksternal adalah metode pembelajaran dan evaluasi pembelajaran. Jika dilihat dari persentase yang diperoleh indikator mengatribusi lebih besar dibandingkan persentase dari indikator mengorganisasi dan membedakan. Hal ini dapat disebabkan karena adanya faktor penghambat yang berasal dari faktor internal dan faktor eksternal. Faktor penghambat yang berasal dari faktor internal adalah intelegensi, minat siswa. Sedangkan faktor penghambat yang berasal dari faktor eksternal adalah lingkungan.

Faktor pendukung pertama berasal dari faktor internal yaitu sumber referensi yang memiliki rata-rata persentase tertinggi sebesar (82,89\%). Dalam menganalisis suatu permasalahan siswa menggunakan internet, buku, dan artikel sebagai sumber referensinya. Informasi yang telah diperoleh siswa melalui buku, internet, majalah dan koran, kemudian dianalisis dengan anggota kelompoknya untuk mencari jawaban dari rumusan masalah tersebut (Neilna Yuli, Handoyo, \& Purwito, n.d.) Penggunaan internet sebagai sumber referensi diharapkan dapat membantu siswa dalam mencari berbagai informasi atau pengetahuan yang tidak mereka dapatkan di dalam buku maupun artikel.

Faktor pendukung selanjutnya berasal dari faktor eksternal yaitu metode pembelajaran dengan rata-rata persentase sebesar $(84,86 \%)$. Berdasarkan hasil perhitungan pada tiap-tiap butir angket yang berasal dari sub variabel metode pembelajaran, sebanyak $46,33 \%$ siswa berpendapat bahwa dalam proses pembelajaran pada materi pencemaran lingkungan guru menggunakan metode pembelajaran berbasis masalah (Problem Based Learning), hal tersebut juga diperkuat berdasarkan hasil wawancara dengan guru biologi di SMA Negeri 4 Kota Bekasi yang mengatakan bahwa untuk meningkatkan kemampuan analisis siswa salah satu metode yang sering digunakan adalah metode pembelajaran berbasis masalah (Problem Based Learning). Dalam menerapkan metode pembelajaran berbasis masalah di dalam kelas guru meminta siswa melakukan diskusi dengan teman sekelompoknya untuk mengidentifikasi suatu masalah, merumuskan masalah, mencari informasi dari berbagai sumber dan menyimpulkan hasil pengamatan berdasarkan pada masalah yang terjadi dikehidupan sehari-hari. 
Melalui pembelajaran mandiri dalam kelompok, siswa dapat meningkatkan kemampuan mereka untuk mengekspresikan dan memproses informasi dengan menjelaskan pemahaman mereka sendiri tentang masalah atau dengan menghasilkan pengetahuan yang berguna melalui diskusi kelompok (Gao, Wang, Jiang, \& Fu, 2018).

Faktor eksternal selanjutnya yang menjadi faktor pendukung yaitu evaluasi pembelajaran dengan rata-rata persentase sebesar $(87,06 \%)$. Berdasarkan hasil perhitungan data angket dan hasil wawancara dengan guru biologi di SMA Negeri 4 Kota Bekasi menunjukkan bahwa dalam proses pembelajaran guru sering memberikan tugas kelompok kepada siswa untuk menilai maksud dari suatu permasalahan berdasarkan gambar atau video yang diberikan. Selain itu, setiap akhir pembelajaran guru juga memberikan tes tertulis dengan menggunakan ranah kognitif C4 yang bertujuan agar dapat melatih kemampuan siswa dalam menganalisis suatu masalah. Semakin sering seseorang melakukan latihan, maka kemampuan analisisnya juga akan semakin terlatih (Nisa, Disman, \& Dahlan, 2018).

Faktor selanjutnya adalah faktor yang menghambat siswa dalam meningkatkan kemampuan analisisnya yang berasal dari faktor internal yaitu intelegensi dan minat siswa, faktor eksternal yaitu lingkungan. Faktor pertama yang dapat menghambat kemampuan berpikir analisis siswa berasal dari intelegensi dengan rata-rata persentase sebesar $(47,76 \%)$. Rendahnya persentase disebabkan karena siswa masih mengalami kesulitan dalam menemukan sebuah solusi, dan membedakan antara bagian penting dan tidak penting dari suatu materi atau permasalahan. Kegiatan menganalisis bertujuan untuk mengembangkan kemampuan siswa dalam membedakan fakta dari opini, mengungkapkan ide, membedakan materi yang relevan dan tidak relevan, membuat hipotesis atau kesimpulan, dan mampu menangkap pendapat-pendapat yang tersirat (Anderson \& Krathwohl, 2010). Kesulitan yang dialami oleh siswa juga berpengaruh terhadap rendahnya hasil analisis data pada indikator membedakan dan indikator mengorganisasi.

Faktor internal selanjutnya yang dapat menghambat kemampuan berpikir analisis yaitu minat siswa dengan rata-rata persentase sebesar $(60,20 \%)$. Hal ini disebabkan karena siswa masih kurang berminat dalam membaca atau mengoleksi buku analisis sebagai sumber belajarnya, selain itu siswa juga hanya sesekali mencoba untuk membuat pertanyaan atau soal-soal dengan ranah kognitif $\mathrm{C} 4$. (Slameto, 2013) mengatakan bahwa jika terdapat siswa yang kurang berminat terhadap suatu kegiatan, maka minat siswa dapat ditingkatkan dengan cara menjelaskan hal-hal yang menarik dan manfaat yang akan ditimbulkan bagi kehidupan.

Faktor terakhir yang dapat menghambat kemampuan berpikir analisis siswa yang berasal dari faktor eksternal yaitu lingkungan dengan rata-rata persentase sebesar $(52,82 \%)$. Berdasarkan hasil perhitungan pada tiap-tiap butir angket yang 
berasal dari sub variabel lingkungan, sebanyak 50,49\% siswa berpendapat bahwa saat berada di rumah mereka hanya sesekali diajak berdiskusi oleh keluarga mereka untuk menganalisis suatu hal atau permasalahan yang sedang terjadi di Indonesia. Padahal kegiatan tersebut dapat mendorong dan membimbing siswa untuk meningkatkan kemampuan analisis dan prestasi belajar mereka. Apabila siswa dan keluarganya meluangkan waktu cukup di rumah untuk proses belajar-mengajar pasti pada saat tes siswa atau anak tersebut akan mudah menjawab soal karena telah sering berlatih dengan begitu siswa juga akan mendapatkan prestasi belajar yang baik (Sriyono \& Wahyudin, 2016). Selain itu, teman sebaya juga kurang berperan dalam meningkatkan kemampuan analisis siswa karena mereka hanya sesekali melakukan diskusi dengan teman sebaya mereka dalam menganalisis suatu permasalahan dengan persentase sebesar 53,46\%. Adanya kelompok teman sebaya diharapkan siswa dapat saling bertukar pikiran untuk menyelesaikan tugas sekolah mereka dalam memecahkan masalah, berdiskusi mengenai kesulitan belajar, belajar bersama untuk menghadapi ujian sekolah dan saling memotivasi antar anggota dalam hal belajar (Aziz, Tarmedi, \& Untung, 2015)

\section{Kesimpulan}

Berdasarkan pemaparan diatas bahwa kemampuan berpikir analisis siswa kelas XI MIPA 1, XI MIPA 3 dan XI MIPA 4 di SMA Negeri 4 Kota Bekasi termasuk kedalam kategori baik dengan rata-rata $73 \%$. Terdapat faktor pendukung dan faktor penghambat yang mempengaruhi kemampuan berpikir analisis siswa yang berasal dari faktor internal dan faktor eksternal. Faktor pendukung yang berasal dari faktor internal dan eksternal adalah sumber referensi, metode pembelajaran, dan evaluasi pembelajaran dengan rata-rata persentase sebesar $82,89 \%, 84,86 \%$ dan 87,06\%. Sedangkan faktor penghambat yang yang berasal dari faktor internal dan eksternal adalah intelegensi, minat siswa dan lingkungan dengan rata-rata persentase sebesar 47,76\%, 60,20\% dan $52,82 \%$. 


\section{BIBLIOGRAFI}

Anderson, Lorin W., \& Krathwohl, David R. (2010). Kerangka landasan untuk pembelajaran, pengajaran, dan asesmen. Yogyakarta: Pustaka Pelajar, 300(300), 0.

Arikunto, Suharsimi. (2009). Dasar-dasar Evaluasi Pendidikan (edisi revisi).

Aziz, Muhamad Abdul, Tarmedi, Ewo, \& Untung, Sunarto H. (2015). Hubungan Antara Kelompok Teman Sebaya Dengan Prestasi Belajar Siswa SMKN. Journal of Mechanical Engineering Education, 2(2), 233-238.

Djiwandono, Patrisius Istiarto. (2013). Kemampuan Analisis Sebagai Bekal Bernalar Kritis. Malang: Malang Pos.

Firdaus, Dicky Fauzi. (2017). Pengaruh Metode Discovery Dan Metode Problem Solving Terhadap Kemampuan Berpikir Kritis. Syntax Literate; Jurnal Ilmiah Indonesia, 2(10), 7-13.

Gao, Shuang, Wang, Yuxin, Jiang, Bin, \& Fu, Ying. (2018). Application of problembased learning in instrumental analysis teaching at Northeast Agricultural University. Analytical and Bioanalytical Chemistry, 410(16), 3621-3627. https://doi.org/https://doi.org/10.1007/s00216-018-1025-7

Neilna Yuli, E., Handoyo, Budi, \& Purwito, Hendri. (n.d.). Model Pembelajaran Group Investigation (GI) Terhadap Kemampuan Berpikir Analisis.

Ngalim, Purwanto. (2011). Evaluasi Hasil Belajar. Yogyakarta: Pustaka Pelajar.

Nisa, Hayatin, Disman, \& Dahlan, Dadang. (2018). Pengaruh Penerapan Model Pembelajaran Kolaboratif Teknik Group Investigation Terhadap Kemampuan Berpikir Analisis Peserta Didik. Manajerial, 3(5), 157-166.

PISA, OECD. (2016). Prograamme for International Student Assessement (PISA) Results From PISA 2015. Publishing.

Prawita, W., \& Prayitno, B. A. (2019). Students' profile about analytical thinking skill on respiratory system subject material. Journal of Physics: Conference Series, 1157(2), 22078. IOP Publishing.

Rahma, Alina Dwi, Sulhadi, \& Sumarti, Sri Susilogati. (2016). Implementasi Pembelajaran Sains dengan Media Fotonovela untuk Meningkatkan Motivasi Belajar Siswa SD/MI. Journal of Primary Education, 5(1), 1-9.

Slameto. (2013). Belajar \& Faktor-Faktor yang Mempengaruhi. Jakarta: PT. Rineka Cipta.

Sriyono, Heru, \& Wahyudin. (2016). Peran Tingkat Intelegensi dan Motivasi Belajar dalam Meningkatkan Prestasi Belajar Ekonomi di SMA Negeri Gugus 01 
Eka Kartikawati, Astri Fajar Cahyani dan Gufron Amirullah

Kabupaten Tangerang. Research and Development Journal of Education, 3(1), 5269.

Sudibyo, Elok, Jatmiko, Budi, \& Widodo, Wahono. (2016). The Effectiveness of CBL Model to Improve Analytical Thinking Skills the Students of Sport Science. International Education $\quad$ Studies, 9(4), 195-203. https://doi.org/10.5539/ies.v9n4p195

Suharsimi, Arikunto. (2006). Prosedur penelitian suatu pendekatan praktik. Jakarta: Rineka Cipta.

Sulastri, Sulastri, Safahi, Luthpi, \& Susilo, Susilo. (2018). Pengaruh Strategi Pembelajaran Critical Incident terhadap Keterampilan Analisis Siswa. Assimilation: Indonesian Journal of Biology Education, 1(2), 77-81.

Thaneerananon, Taveep, \& Triampo, Wannapong. (2016). Development of a Test to Evaluate Students' A nalytical Thinking Based on Fact versus Opinion Differentiation. International Journal of Instruction, 9(2). https://doi.org/10.12973/iji.2016.929a

Triwiyanto, Teguh. (2014). Pengantar Pendidikan. Jakarta: PT Bumi Aksara. 